\title{
Pengaruh Terapi Akupunktur terhadap Metabolisme Glukosa pada Penderita Overweight dan Obesitas di Kelurahan Mojosongo, Surakarta
}

\author{
Maria Dewi Christiyawati ${ }^{1}$, Sumanto ${ }^{2}$ Purwanto $^{3^{*}}$ \\ 1,2,3 Poltekkes Kemenkes Surakarta Jurusan Akupunktur \\ *Email: purwanto.akp@gmail.com
}

\begin{abstract}
Background: Obesity is a multifactorial disease, which occurs as a result of excessive fat tissue accumulation and if not treated properly in the long term will lead to risks and complications of dangerous diseases including diabetes mellitus, cardiovascular disease, reproductive system disorders, gallstones, and bone diseases and joints. The purpose of this study is to determine the effect of acupuncture on glucose metabolism in overweight and obese patients. Methods: This study uses a quasiexperimental one-group pretest-posttest design. This research was conducted at the Posyandu Elderly in Mojosongo, Jebres, Surakarta. This study focuses on acupuncture therapy on blood glucose levels, body mass index (BMI) and serum Hb.Alc levels before and after acupuncture therapy. Data analysis using Paired T-Test with SPSS Series 23 data processing application. Results: Showed that there was a significant but not significant effect of acupuncture on blood glucose levels in overweight and obese patients $(\rho=0,524)$, there was a significant effect of acupuncture on Body Mass Index (BMI) in overweight and obese patients $(\rho=0,019)$, and there is a significant effect of acupuncture on Hb.Alc levels in overweight and obese patients( $\rho=0,000)$. Conclusion: This study shows that acupuncture therapy can affect glucose metabolism and reduce body mass index so as to prevent the onset of dangerous chronic diseases in the future.
\end{abstract}

Keywords: overweight-obesity, acupuncture, body mass index (BMI), blood glucose levels, Hb.Alc.

\section{PENDAHULUAN}

Kegemukan atau obesitas merupakan suatu kondisi multifaktorial, yang terjadi akibat menumpuknya jaringan lemak secara berlebihan, sehingga dapat mengganggu kesehatan (Sudoyo, 2009). Obestas termasuk pada penyakit yang terkait sindrom metabolic seperti halnya hipertensi, dislipidemia, dan resistensi insulin (R.H. Eckel et.al, 2005).

World Health Organization (2008) menjelaskan bahwa obesitas dan kelebihan berat badan dapat menimbulkan risiko yang serius pada terjadinya penyakit kronis yang berhubungan dengan diet, termasuk diabetes tipe 2. WHO (2016) menyebutkan bahwa 39\% perempuan dan 39\% laki-laki berusia di atas 18 tahun mengalami overweight dan $15 \%$ wanita, sedangkan $11 \%$ pria mengalami obesitas. Dengan begitu terdapat hampir 2 milyar orang dewasa di dunia yang mengalami overweight dan lebih dari setengah milyar mengalami obesitas.

Overweight dan obesitas yang tidak dilakukan penanganan dengan baik maka dalam waktu jangka panjang akan menimbulkan resiko maupun komplikasi terjadinya penyakit berbahaya meliputi diabetes mellitus, penyakit cardiovaskuler, gangguan sistem reproduksi, batu empedu, maupun penyakit tulang dan sendi (Flier et. al., 2005)

Seseorang yang mengalami kegemukan/obesitas, terdapat kelebihan kalori akibat diet berlebih (terutama yang mengandung gula/glukosa) akan menimbulkan penumpukan lemak di jaringan subkutan. Akibatnya, terjadi resistensi insulin pada daerah yang 
mengalami penumpukan lemak, dan selanjutnya dapat menghambat kerja insulin di jaringan tubuh dan otot yang menyebabkan glukosa tidak dapat diangkut ke dalam sel dan terjadi akumulasi di dalam pembuluh darah. Akumulasi glukosa dapat meningkatkan kadar glukosa dalam darah sehingga berisiko pada terjadinya diabetes mellitus tipe 2 (Kulie, et al., 2011).

Akupunktur sebagai salah satu bentuk terapi dengan sejarah ribuan tahun dilaporkan memiliki efek positif terhadap overweight maupun obesitas. Penelitian klinis maupun eksperimental menunjukkan bahwa selain akupunktur dapat menurunkan berat badan juga dapat menurunkan kadar glukosa plasma darah dan memperbaiki resistensi insulin (M. Belivani et.a.l, 2013).

Pemeriksaan serum HbA1C adalah suatu bentuk pemeriksaan laboratorium yang bertujuan untuk memprediksi timbulnya penyakit DM dengan mengetahui derajat metabolism glukosa darah selama 2-3 bulan terakhir. International Expert Committe menetapkan pentingnya pemeriksaan serum $\mathrm{HbA1C}$ dalam skrining diagnosa penyakit DM (American Diabetic Association, 2014).

Indeks Massa Tubuh (IMT) atau Body Mass Index (BMI) merupakan indikator yang paling umum dipakai dan mudah diaplikasikan untuk mengukur level overwight dan obesitas pada orang dewasa. Untuk perhitungan IMT digunakan indeks Quetelet, yaitu berat badan dalam kilogram $(\mathrm{kg})$ dibagi tinggi dalam meter kuadrat $\left(\mathrm{m}^{2}\right)$. Perlu ketelitian pengukuran karena IMT menggunakan ukuran tinggi badan. Hubungan antara lemak tubuh dan IMT ditentukan oleh bentuk tubuh dan proporsi tubuh, sehingga hasil pengukuran IMT belum tentu menggambarkan kegemukan yang sama bagi semua orang dalam sebuah populasi (Sudoyo, 2009).

Hemoglobin A1c atau HbA1c adalah suatu komponen minor dari hemoglobin yang berikatan dengan glukosa. HbA1c juga bisa disebut sebagai hemoglobin glikosilasi atau glikosilasi atau glycohemoglobin. Kadar HbA1c mengindikasikan kondisi jangka panjang dalam pengaturan kadar glukosa darah, bisa juga digunakan untuk memonitor efek diet, olahraga, dan terapi obat terhadap kadar glukosa darah pasien. Hasil pengukuran $\mathrm{HbA1c}$ yang diharapkan untuk penderita diabetes adalah kurang dari 7\%. Semakin tinggi kadar Hb.A1c, semakin tinggi risiko komplikasi yang akan timbul akibat penyakit diabetes melitus. (Kee JL, 2003)

Glukosa merupakan karbohidrat terpenting dalam penyediaan energi di dalam tubuh. Selain akan berperan sebagai bahan bakar bagi proses metabolisme, glukosa juga berperan sebagai sumber energi utama kinerja otak. (Irawan, 2007).

Penelitian oleh Sudaryantoanto L. dkk,(2015) tentang kadar Hb.A1c dan rasio lipid pada wanita dewasa dengan obesitas sentral menunjukan adanya perbedaan nilai $\mathrm{HbA1c}$ dan profil lipid antara kelompok wanita dewasa dengan obesitas sentral dan tanpa obesitas sentral. Mingjuan Han et.al., (2017) melakukan penelitian untuk mengetahui perubahan lingkar pinggang, berat badan, $\mathrm{HbA1c}$, trigliserida, dan cholesterol total setelah terapi akupunktur. Hasilnya Akupunktur menurunkan nilai lingkar pinggang, berat badan, Hb.A1c, trigliserida, dan cholesterol total dan tekanan darah. 


\section{METODE PENELITIAN}

Penelitian ini merupakan penelitian kuantitatif dengan menggunakan menggunakan desain pre eksperimen dengan pre dan post test design, dilaksanakan di Posyandu Lansia Mojosongo dengan populasi penderita overweigh dan obesitas sebesar 25 orang.

Sampel ditentukan dengan purposive sampling dengan kriteria inklusi: pria dan wanita dengan overweight dan obesitas, usia $40-70$ tahun, tidak sedang menggunakan obat antidiabet dan terjaring 13 orang sebagai sampel penelitian. Sampel dilakukan pemeriksaan indeks massa tubuh (IMT), kadar glukosa darah (GDS) dan kadar serum Hb.A1c sebelum dan sesudah tindakan akupunktur.

Tindakan akupunktur dilakukan berdasarkan hasil pemeriksaan abdomen (Hara) dengan cara palpasi untuk mencari Reflex Zone (RZ) dan menentukan diagnosis akupunktur. Titik yang digunakan meliputi Daling (PC.7), Quchi (LI.11), Taibai (SP.3), Taichong (LR.3), Sanyinjiao (SP.6), Zusanli (ST.36), Yinlingquan (SP.9), Taixi (KI.3), Fuliu (KI.7), Yanglingquan (GB.34). Terapi akupunktur dilakukan dua kali dalam seminggu.

Data dianalisis secara univariat (mean, modus, median, dan standar deviasi) dan bivariate menggunakan uji Paired t-test untuk mengetahui perbedaan IMT, GDS, dan HbA1c sebelum dan sesudah tindakan akupunktur dengan signifikansi statistik $(\rho) \leq 0,05$. Semua kalkulasi statistik menggunakan aplikasi SPSS seri 23.

\section{HASIL PENELITIAN}

Subyek penelitian terdiri dari 1 orang laki-laki dan 13 orang perempuan, 9 orang $(64,3 \%)$ berusia $60-69$ tahun, 3 orang $(21,4 \%) 50$ - 59 tahun dan 2 orang (14,3\%) 40 -49 tahun. Pekerjaan subyek penelitian sebanyak 9 orang $(64,3 \%)$ adalah pensiunan dan sisanya adalah ibu rumah tangga dan pegawai negeri sipil (PNS). Rata-rata kadar glukosa darah sebelum tindakan akupunktur adalah $119,93 \mathrm{mg} / \mathrm{dL}$ dan rata-rata kadar glukosa darah sesudah tindakan akupunktur adalah $113,86 \mathrm{mg} / \mathrm{dL}$. Hal ini berarti terjadi penurunan sebesar 6,07 $\mathrm{mg} / \mathrm{dL}$. Indeks massa tubuh (IMT) sebelum tindakan akupunktur sebesar $30,36 \mathrm{Kg} / \mathrm{m}^{2}$ dan sesudah tindakan akupunktur sebesar $30,00 \mathrm{Kg} / \mathrm{m}^{2}$. Hal ini menunjukkan terjadi penurunan indeks massa tubuh (IMT) sebesar $0,36 \mathrm{Kg} / \mathrm{m}^{2}$. Kadar Hb.A1c sebelum tindakan akupunktur adalah 5,8\% dan sesudah tindakan akupunktur adalah $6,4 \%$. Hal ini menunjukkan terjadi kenaikan kadar Hb.A1c sebesar 0,6\%.

Nilai t hitung pengaruh akupunktur terhadap kadar gula darah penderita overweight dan obesitas adalah 0.655 dengan signifikansi probabilitas (Sig) 0,524. Karena signifikansi probabilitas (Sig.) 0,524>0,05 maka tidak terdapat pengaruh signifikan dari akupunktur terhadap kadar gula darah pada penderita overweight dan obesitas. Nilai t hitung pengaruh akupunktur terhadap indeks massa tubuh (IMT) penderita overweight dan obesitas adalah 2.687 dengan signifikansi probabilitas (Sig) 0,019. Karena signifikansi probabilitas (Sig.) $0,019<0,05$ maka terdapat pengaruh signifikan dari akupunktur terhadap IMT pada penderita overweight dan obesitas. Nilai $t$ hitung pengaruh akupunktur terhadap kadar Hb.A1c penderita overweight dan obesitas adalah -9.167 dengan probabilitas (Sig) 0,000. Karena signifikansi probabilitas (Sig.) 0,000<0,05 
maka terdapat pengaruh signifikan dari akupunktur terhadap kadar Hb.A1c pada penderita overweight dan obesitas.

\section{PEMBAHASAN}

Hasil analisis data pada penelitian ini menunjukkan ada pengaruh tindakan akupunktur terhadap kadar glukosa darah pada penderita obestitas dan overweight, namum tidak signifikan $\rho=0,524(\rho>0,05)$. Hasil ini berbeda dengan hasil penelitian yang dilakukan oleh Kazemi AH et.al (2019) yang menyatakan bahwa akupunktur secara signifikan menurunkan kadar glukosa darah puasa dibandingkan dengan sham acupuncture. Namun hasil ini didukung oleh Liang et.al. (2011) yang mengemukakan bahwa akupunktur meningkatkan kadar glukosa darah puasa dengan menjaga kadar insulin melalui stimulasi skeletal muscle Sirtuin 1 (SIRT1)/peroxisome proliferatoractivated receptor $\gamma$ coactivator $1 \alpha(\mathrm{PGC}-1 \alpha)$, yang memberi keyakinan bahwa akupunktur mencegah terjadinya resistensi insulin.

Hasil analisis data pada penelitian ini menunjukkan bahwa ada pengaruh signifikan tindakan akupunktur terhadap indeks massa tubuh (IMT) pada penderita obesitas dan overweight dengan signifikansi sebesar 0,019 $(\rho>0,05)$. Hasil ini sejalan dengan hasil penelitian yang dilakukan oleh Zhang HM et.al. (2017) yang menyatakan bahwa kombinasi akupunktur dan konsultasi nutrisi efektif menurunkan indeks massa tubuh (IMT) dan prosentase lemak tubuh pada penderita obesitas. Zhang K et.al. (2018), berpendapat bahwa efektifitas akupunktur pada kasus obesitas dimungkinkan karena regulasi neuroendocrin.

W. Shen et.al. (2014), mengemukakan bahwa akupunktur menyebabkan remodeling white adipose tissues (WAT) dan brown adipose tissue (BAT) melalui induksi uncoupling protein-1 (UCP1). Hal ini berefek pada perbaikan komposisi lemak tubuh sehingga dapat menjaga indeks massa tubuh (IMT).

Hasil analisis pada penelitian ini menunjukkan bahwa akupunktur berpengaruh pada kadar $\mathrm{Hb} . \mathrm{A} 1 \mathrm{c}$ pasien overweight dan obesitas dengan signifikansi sebesar $0,00(\rho>0,05)$. Namun dalam penelitian ini menunjukkan bahwa t hitung bernilai -9.167 yang berarti ada kenaikan signifikan $\mathrm{Hb}$.A1c sebelum dan setelah tindakan akupunktur. Hal ini berbeda dengan penelitian yang dilakukan oleh Tur et. al. (2015) yang menyatakan bahwa akupunktur secara signifikan menurunkan kadar Hb.A1c pada penderita obesitas. Hasil penelitian ini juga berbeda dengan penelitian yang dilakukan oleh Nabila (2018) bahwa terjadi hubungan positif bahwa penurunan kadar glukosa darah puasa berkorelasi dengan penurunan kadar Hb.A1c.

Dalam penelitian ini peneliti mengalami keterbatasan dalam mengendalikan variable pengganggu. Variabel ini berperan cukup kuat dalam mempengaruhi hasil penelitian. Hal ini disebabkan karena pada saat pengukuran glukosa darah, indeks massa tubuh (IMT) dan serum Hb.A1c dilakukan ketika pasien sedang menjalankan ibadah puasa bulan Ramadhan. Pada saat seseorang menjalankan ibadah puasa kebutuhan energy tubuh tidak lagi diambil dari asupan glukosa melainkan diambil dari metabolism keton dan pemecahan lemak menjadi glukosa (Wardhani AK, 2012).

Saat seseorang berpuasa, akan terjadi penurunan sekresi insulin yang menyebabkan kadar gula darah menjadi naik, yang kemudian berakibat pada 
peningkatan kerja dari hormon kontra insulin yakni glucagon dan katekolamin yang menghasilkan glukosa dari pemecahan glikogen (PERKENI, 2014). Ketika seseorang berpuasa beberapa jam, cadangan glikogen mulai berkurang, akibat dari berkurangnya insulin dalam sirkulasi sehingga menimbulkan asam lemak. Asam lemak selanjutnya dipecah untuk menghasilkan energi (Smeltzer \& Bare, 2014) Hal ini dibuktikan dengan penurunan rata-rata glukosa darah yang tidak terlalu signifikan $(6,07 \mathrm{mg} / \mathrm{dL})$, ratarata indeks massa tubuh (IMT) mengalami penurunan yang signifikan $\left(0,36 \mathrm{~kg} / \mathrm{m}^{2}\right)$ sedangkan $\mathrm{Hb} . \mathrm{A} 1 \mathrm{c}$ justru mengalami kenaikan rata-rata sebesar $0,6 \%$. Munigar (2013) menyatakan bahwa saat seseorang berpuasa di bulan ramadhan, maka akan sangat berpengaruh terhadap penurunan berat badan. Selama menjalankan ibadah puasa ramadhan tubuh lebih sedikit memerlukan energy (Khan et.al, 2002).

Secara umum penelitian ini juga sejalan dengan penelitian oleh Shi et.al. (2018) yang mengungkapkan bahwa akupunktur berperan pada penurunan glukosa darah, indeks masssa tuhuh dan level hemoglobin terglikolisasi (Hb.A1c) sehingga akupunktur berpotensi terhadap pencegahan diabetes mellitus tipe 2 . Dalam pemahaman akupunktur klasik obestas dipandang sebagai bentuk ketidak seimbangan, sedangkan ketidak seimbangan adalah awal mula terjadinya penyakit. Akupunktur berperan pada perbaikan keseimbangan tubuh dengan memperbaiki fungsi organ terkait dan meridian sebagai jalur energi (T. Tjohjo, 2005). Selain itu akupunktur memiliki peran reaksi antiinflamasi dan penurunan berat badan pada pasien obesitas sehingga akupunktur juga dapat dimanfaatkan untuk pencegahan penyakit inflamatorik (Ismail et.al, 2015).

\section{KESIMPULAN}

Penelitian ini menunjukkan bahwa terapi akupunktur dapat mempengaruhi metabolisme glukosa dan menurunkan indeks massa tubuh sehingga dapat mencegah resiko timbulnya penyakit kronis berbahaya di masa mendatang. Penelitian selanjutnya diharapkan dapat lebih bisa mengendalikan variabel pengganggu dan dengan populasi dan sampel yang lebih besar.

\section{DAFTAR RUJUKAN}

Agus Dharma. (2001). Manajemen Supervisi. Jakarta: Raja Grafindo Persada

Arora, M., Koley, S., Gupta, S., et al, (2007). A Study on Lipid Profile And BodyFat in Patients with Diabetes Melitus. Anthropologist, 9(4):295-8.

Flier, J.S., Flier E.M., (2005). Obesity.In: Kasper, D.L., Braunwald, E., Fauci,A.S., Hauser, S.L., Longo, D.L., Jameson, J.L.,2007. Harrison's Principles of Internal Medicine 6th ed. McGraw -Hill: 422-30.

Hales CM, Carroll MD, Fryar CD, Ogden CL (2017). "Prevalence of Obesity Among Adults and Youth: United States, 20152016". NCHS Data Brief (288): 1-8

$$
\begin{gathered}
\text { Haslam DW, James } \\
\text { "Obesity". } \\
\text { (9492): }
\end{gathered}
$$


Irawan, M. A., (2007). Glukosa dan Metabolisme Energi. Sport Science Brief. 1(6) :12-5.

Ismail LAA, Ibrahim AA, Latif GA, ElHaleem, Helmy G, Labib LM, ElMasry MK. (2015). Effect of Acupuncture on Body Weight Reduction and Inflamatory Mediators inEgyptian Obese Patients. Open Access Macedonian Journal of Medical Sciences. Maret 2015 Vol 3 (1): $85-90$ http://dx.doi.org/10.3889/oamjms.20 15.010

Jones AG, Hattersley AT (2013). "The clinical utility of C-peptide measurement in the care of patients with diabetes". Diabetic Medicine. 30 (7): $\quad 803-17$. doi:10.1111/dme.12159.

PMC 3748788. PMID 23413806.

Kazemi AH, Wang W, Wang Y, Khodaie F, Rezaezadeh H. (2019). Therapeutic Effects of Acupuncture on Blood Glucose Level Among Patients With Type-2 Diabetes Mellitus: A Randomized Clinical Trial. Journal of Traditional Chinese Medical Sciences. Vol 6: 101-107. https://doi.org/10.1016/j.jtcms.2019. 02.003

Kee JL, (2003). Pedoman Pemeriksaan Laboratorium \& Diagnostik.Jakarta EGC

Khan A, Khattak M A Khan. "Islamic Fasting, An Effective for Prevention and Control of Obesity". (2002) Journal of Nutrition,Pakistan
Kulie, T., Slattengren, A., Redmer, J., Counts, H., Eglash, A., and Schrager, S., (2011). Obesity and Women's Health: An EvidenceBased Review, JABFM, 24(1), 75.

Lau DC, Douketis JD, Morrison KM, Hramiak IM, Sharma AM, Ur E (2007). "2006 Canadian clinical practice guidelines on the management and prevention of obesity in adults and children [summary]". CMAJ (Practice Guideline, Review). 176 (8): S1-13. doi:10.1503/cmaj.061409

Liang, F., Chen, R., Nakagawa, A., Nishizawa, M., Tsuda, S., Wang, H., et al. (2011). Low-frequency electroacupuncture improves insulin sensitivity in obese diabetic mice through activation of SIRT1/PGC1alpha in skeletal muscle. EvidenceBased Complementary and Alternative Medicine, 2011, 735297. http://dx.doi.org/10.1155/2011/7352 97

M. Belivani, C.Dimitroula, N. Katsiki, M. Apostolopoulou,M.Cummin gs, and A. I.Hatzitolios, (2013). "Acupuncture in the treatment of obesity: a narrative review of the literature," Acupuncture inMedicine, Vol. 31, No. 1, pp. 88-97.

Nabila. (2018). Hubungan Kadar Hb.A1c Dengan Kadar Glukosa Darah Puasa Pada Pasien Penderita Diabetes Melitus Tipe 2 Di Rumah Sakit Umum Pusat Haji Adam Malik. Skripsi. Program Studi Pendidikan Dokter Fakultas Kedokteran Universitas Sumatera Utara. 
http://repositori.usu.ac.id/handle/123 456789/10945

Perkeni. (2015). Pengelolaan dan Pencegahan Diabetes Mellitus Tipe II di Indonesia; Panduan Penatalaksanaan DM Tipe II pada Individu Dewasa di Bulan Ramadan. http.www.pbperkeni.or.id

R. H. Eckel, S. M. Grundy, and P. Z. Zimmet,(2005)."The metabolic syndrome," The Lancet, vol. 365, no. 9468 , pp. 1415-1428,

Rahmanida YP, (2016). Hubungan Antara Jenis Pekerjaan Dengan Obesitas Pada Penduduk Dewasa Di Daerah Perkotaan Di Indonesia (Analisis Data Indonesian Family Life Survey Gelombang Ke-5). Tesis. http://etd.repository.ugm.ac.id

Schteingart, D.E, (2005), Metabolisme Glukosa dan Diabetes Mellitus, dalam Patofisiologi Konsep Klinis Proses-Proses Penyakit, Edisi VI, volume 1, hal. 1259-1270, Penerbit Buku Kedokteran EGC, Jakarta.

Shi.L, Feng.L, Yang. Y, Li.X, Zhang M, Zhang Y, Ni Q. (2018). Prevention of Type 2 Diabetes Mellitus With Acupuncture-Protocol for a Systematic review and metaanalysis. Medicine. 97:48.

Smeltzer, \& Bare. (2014). Keperawatan Medikal Bedah Brunner \& Suddart ed 12. Jakarta: EGC.

Soegondo, S., (2004), Pengobatan dengan Insulin, dalam Noer, S.,Ilmu Penyakit Dalam, Jilid 1, Edisi III,
Cetakan ke -7, 665-667, Balai Penerbit Fakultas Kedokteran Universitas Indonesia, Jakarta

Soewondo, P., (2002). Pemantauan Pengendalian Diabetes Melitus.Dalam Penatalaksaan Diabetes Melitus Terpadu. Jakarta: FKUI

Sudoyo, A.W., (2009). Buku Ajar Ilmu Penyakit Dalam, Jilid III Edisi IV. Jakarta: FKUI, 1919-1925.

T. Tjohjo, W. (2005). Tusuk Jarum Meredam Lapar. Diaskes tanggal 1 Mei 2006, http://www.indomedia.com/tips sehat.mht.

Tur, FC. (2015). Weight loss therapy with acupuncture effecting Hb.A1c levels. Journal Diabetes Metabolic.6:8. $\quad$ http: //dx.doi.org/10.4172/2155$\underline{6156 . C 1.030}$

W. Shen, Y.Wang, S.-F. Lu et al., (2014) "Acupuncture promotes white adipose tissue browning by inducing UCP1 expression on DIO mice," BMC Complementary and Alternative Medicine, vol. 14, no. 1, article 501.

Wardhani Ak, (2012). https://www.tribunnews.com/ramad an/2012/07/23/ini-keajaibanmetabolisme-pada-tubuh-saat-puasa.

WHO. Global Health Observatory (GHO) data. Overweight and obesity. http://www.who.int/gho/ncd/risk_fa 
20 Jurnal Keterapian Fisik, Volume 5, No 1, Mei, hlm 1-61

ctors/overweight_text/en/ diakses 8 Maret 2018

Zhang HM, Wu XL, Jiang C, Shi RX. (2017). Effect of Acupuncture Therapy on Body Compositions in Patients With Obesity. Zhen Ci Yan Jiu. 25 April. Vol 42 (2): 173-7

Zhang K, Zhou S, Wang C, Xu H, Zhang L. (2018). Acupuncture on Obesuty: Clinical Evidence and Possible Neuroendocrine Mechanism. Evidence-Based Complementary and Alternative Medicine. Vol 2018. https://doi.org/10.1155/2018/640938 9 